\title{
ANALISIS PEMASARAN IKAN KOI (Cyprinus carpio) DI PASAR IKAN HIAS JALAN SUMENEP, JAKARTA PUSAT
}

Oleh:

Reynaldo Silalahi ${ }^{1}$ Yudha Lestira Dhewantara ${ }^{2}$

1. Mahasiswa Program Studi budidaya perairan Fpik USNI

2. Dosen program studi budidaya perairain FPIK USNI

\begin{abstract}
ABSTRAK
Penelitian ini bertujuan menganalisis efisiensi pemasaran ikan koi (Cyprinus carpio) di Pasar Ikan Hias Jalan Sumenep, Jakarta Pusat. Penelitian bertujuan untuk menganalisa saluran pemasaran ikan koi dan efesiensi tiap saluran pemasaran. Penelitian ini dilakukan sejak Juli 2017 hingga Maret 2018. Penelitian ini menggunakan metode survei. Teknik pengambilan sampel yang dilakukan adalah sensus. Data diperoleh dari wawancara langsung dengan 15 pedagang. Data hasil penelitian dianalisis secara deskripsi, parameter yang dianalisis meliputi keragamaan biaya manfaat (BCR), margin pemasaran, dan rasio keuntungan terhadap biaya.

Terdapat dua pola saluran pemasaran ikan koi (Cyprinus carpio) di Pasar Ikan Hias Jalan Sumenep, Jakarta Pusat. Saluran 1 terdiri dari pembudidaya, pengumpul, pedagang dan konsumen yang memiliki rataan BCR: 1,43. Saluran 2 terdiri dari pembudidaya, pedagang dan konsumen yang memiliki BCR: 1,51. Melihat BCR dari tiap saluran yang $B C R \geq 1$ maka status saluran pemasaran layak untuk dikembangkan. Saluran 2 memiliki saluran pemasaran yang lebih efisien. Hal ini disebabkan pedagang langsung membeli ikan koi dari pembudidaya dan memasarkan kepada konsumen sehingga harga beli yang rendah dan harga jual yang tinggi. Semakin ringkas saluran pemasaran maka keuntungan yang diperoleh dari tiap lembaga pemasaran lebih besar
\end{abstract}

Kata Kunci : ikan koi; pemasaran; metode survei; pasar ikan hias jalan sumenep; pemasaran; keragaman biaya manfaat (BCR): saluran pemasaran. 


\section{PENDAHULUAN}

Ikan hias merupakan salah satu dari bagian komoditas perikanan yang bernilai ekonomis tinggi. Prospek bisnis ikan hias di Indonesia cukup cerah. Potensi perairan Indonesia mencakup $70 \%$ total wilayah $\left(3,1\right.$ juta $\left.\mathrm{km}^{2}\right)$ memiliki potensi untuk pengembangan usaha disektor perikanan. Pasar ekspor utama tersebar di Asia dan UniEropa. Dalam usaha ikan hias, terdapat dua jenis komoditi ikan hias laut dan tawar. Salah satu jenis ikan hias yang di gemari pada saat ini adalah ikan koi. Ikan yang berasal dari family cyprinidae ini memiliki corak dan warna yang sangat menarik dan memiliki nilai ekomonis yang cukup tinggi dan stabil. Ikan ini umumnya dimiliki oleh kalangan hobiis dikarenakan harganya yang cukup tinggi dan juga memerlukan perawatan khusus.

Pasar pada bisnis modern merupakan faktor penting yang harus diperhatikan sebelum proses dilakukan, karena pasar merupakan tujuan akhir dari proses produksi. Pengertian manajemen pemasaran adalah kegiatan menganalisis, merencanakan, melaksanakan dan mengendalikan program-program yang disusun dalam pembentukan, pembangunan, dan pemeliharaan keuntungan dari pertukaran/ transaksi melalui sasaran pasar dengan harapan untuk mencapai tujuan organisasi (perusahaan) dalam jangka panjang (Assauri 2013).

Kendala yang dihadapi dalam usaha pemasaran ikan koi adalah tiap mata rantai perdagangan merupakan usaha yang berdiri sendiri. Persaingan akan timbul apabila di salah satu komponen dari mata rantai tersebut kekurangan stok sehingga mengakibatkan harga ikan akan menjadi tinggi. . Selain itu, terkait dengan stok ikan di pasar, bila permintaan pasar tidak sesuai dengan stok, stok berlebihan maka pasar akan menurunkan harga supaya tidak kesulitan mengatasi stok berlebihan. Oleh sebab itu, informasi mengenai peluang pasar ikan koi diperlukan dan cukup menarik untuk meneliti prospektif dan faktor-faktor penyebab permasalahan yang dialami tiap lembaga pemasaran.

\section{BAHAN DAN METODE}

Metode penelitian yang digunakan adalah metode deskriptif, yaitu metode yang memberikan gambaran atau uraian atas suatu keadaan sejelas mungkin tanpa ada 
perlakuan terhadap objek yang diteliti. Jenis penelitian deskriptif yang digunakan adalah survei dan wawancara yaitu metode penelitian yang mengambil sampel dari suatu populasi dan menggunakan kuesioner sebagai alat pengumpulan data yang pokok (Russefendi, 2003). Teknik pengambilan sample untuk pedagang, pengumpul dan pembudidaya adalah in depth interview, artinya melakukan wawancara mendalam sampai mendapatkan infomasi yang dibutuhkan . Pengambilan sampel dilakukan untuk konsumen dengan menggunakan metode Purposive Sampling, pengambilan sampel yang dilakukan dengan sengaja berdasarkan karakteristik tertentu yang dianggap mempunyai sangkut paut dengan karakter di lapangan (Nawawi, 2005). Metode Analisis Data yang digunakan berupa;

\section{Analisis Prospektif}

Analisis ini bertujuan untuk mengetahui besarnya keuntungan yang diperoleh dari usaha pemasaran ikan hias yang dilakukan oleh pelaku pemasaran dalam satu tahun. Analisis usaha terdiri atas analisis pendapatan usaha, dan analisis Benefit Cost.

\section{Analisis Pendapatan Usaha}

Cara mengetahui seberapa besar keuntungan yang didapatkan tiap saluran pemasaran. Konsep analisis pendapatan usaha adalah sebagai berikut :

Keuntungan $=$ Penerimaan Total - Biaya Total

$\pi=\mathbf{T R}-\mathbf{T C}$

Dengan kriteria usaha sebagai berikut :

- Penerimaan total > biaya total ; usaha menguntungkan

- Penerimaan total = biaya total : usaha tidak untung dan tidak rugi (impas)

- Penerimaan total < biaya total ; usaha merugikan

\section{Benefit Cost Ratio (BCR)}

Cara mengetahui analisis usaha pada pemasaran ikan hias dengan menggunakan parameter BCR (Mursid, 2004). Perhitungan dilakukan di setiap saluran 
pemasaran Ikan Koi di pasar ikan hias Jalan Sumenep Jakarta. jika dirumuskan sebagai berikut:

$$
\text { BCR }=\frac{\text { Total Penerimaan }}{\text { Total Biaya }}
$$

\section{Analisis Efisiensi Pemasaran}

Efisiensi pemasaran adalah seberapa besar pengorbanan yang harus dikeluarkan dalam kegiatan pemasaran menunjang hasil yang bisa didapatkan dari kegiatan pemasaran tersebut. Efisiensi pemasaran dapat dicari dengan menghitung rasio "keluaran-masukan" dalam kegiatan pemasaran yang dilakukan. Semakin tinggi nilai rasio keluaran-masukan, maka pemasaran yang dilakukan semakin efisien (Kotler, 2005).

\section{Analisis Margin Pemasaran}

Apabila dalam pemasaran suatu produk terdapat lembaga pemasaran yang melakukan fungsi pemasaran, maka marjin pemasaran secara matematis dapat dituliskan sebagai berikut (Sudiyono, 2002)

$\mathrm{MP}=\mathrm{Hk}-\mathrm{Hp}=\mathrm{BM}+\mathrm{K}$

Keterangan :

MP = Margin Pemasaran (Rp/ekor)

$\mathrm{Hk}=$ Harga di tingkat Konsumen (Rp/ekor)

$\mathrm{Hp}=$ Harga di tingkat Produsen (Rp/ekor)

$\mathrm{BM}=$ Biaya Pemasaran (Rp/ekor)

$\mathrm{K}=$ Keuntungan Lembaga Pemasaran (Rp/ekor)

\section{Farmer's Share}

Farmer's share merupakan suatu analisis untuk mengetahui tingkat keuntungan yang didapatkan oleh nelayan. Dalam menentukan besarnya bagian dari akhir yang akan diterima oleh nelayan.

\section{HASIL DAN PEMBAHASAN}




\section{Karakteristik Responden}

Berdasarkan hasil survey dan wawancara di pasar ikan hias Jalan Sumenep, Jakarta Pusat untuk pedagang ikan koi berjumlah belasan orang. Usia termuda dari responden adalah 34 tahun dan tertua dengan usia 62 tahun. Dengan tingkat pendidikan SMP-Sarjana.

\section{Pola Saluran Pemasaran}

Secara umum untuk Pasar Ikan Hias Jalan Sumenep, Jakarta Pusat terdapat 2 pola saluran pemasaran ikan koi. Saluran pemasaran 1 merupakan saluran pemasaran yang melibatkan pembudidaya, pengumpul, pedagang dan konsumen. Saluran pemasaran 2 melibatkan pembudidaya, pedagang, dan konsumen.

\section{Keragaman Biaya Manfaat}

Menurut Sukirno (2008) biaya produksi merupakan semua pengeluaran yang dilakukan perusahaan untuk memperoleh faktor-faktor produksi dan bahanbahan mentah yang akan digunakan untuk menciptakan barang-barang yang diproduksi produsen tersebut. Kriteria finansial yang digunakan antara lain profitabilitas atau keuntungan, Benefit Cost Rasio (BCR).

\section{Pembudidaya}

Pembudidaya membudidayakan ikan di wilayah Blitar maupun Sukabumi yang dikenal sebagai sentra ikan koi. Pembudidaya umumnya meminjam lahan secara tahunan namun ada juga yang memiliki lahan sendiri. Keuntungan pembudidaya adalah sebesar Rp. 39.300.000,00 per tahun. BCR dihitung secara tahunan. Berdasarkan hasil perhitungan nilai BCR dari usaha ini rata-rata sebesar 1.65 .

\section{Pengumpul}

Pengumpul mengumpulkan ikan koi dari berbagai pembudidaya yang menyebar lokasinya dan bertugas pula menyalurkan ke lembaga perantara lainnya. 
Pengumpul biasanya memantau dan memberi bantuan modal kepada pembudidaya. Keuntungan pengumpul adalah sebesar Rp. 9.845.000,00 per bulan. Berdasarkan hasil perhitungan nilai BCR dari usaha ini rata-rata sebesar 1.28 .

\section{Pedagang}

Pedagang merupakan pelaku usaha pemasaran ikan koi yang bertindak sebagai penyalur ikan koi ke konsumen. Biaya tetap terdiri dari biaya penyusutan bak penampung dan biaya penyusutan peralatan produksi. Biaya tidak tetap terdiri dari biaya tenaga kerja, pemeliharaan ikan koi, plastik dan gas $\mathrm{O}_{2}$, jumlah ikan hias yang dibeli. Penerimaan berasal dari produksi berupa jumlah ikan koi yang dijual dikalikan dengan harga jual per ekor.

\section{Efisiensi Pemasaran}

Pengukuran efisiensi dapat dilakukan dengan dua cara, yaitu efisiensi operasional dan efisiensi harga. Efisiensi operasional diukur dari biaya pemasaran dan margin pemasaran. Margin pemasaran merupakan perbedaan harga yang dibayarkan oleh kosumen terakhir dengan harga yang diterima oleh lembaga pemasaran sebelumnya, meliputi biaya dan keuntungan pemasaran. Biaya pemasaran adalah semua biaya yang dikeluarkan untuk mengalirkan barang dari satu lembaga ke lembaga pemasaran lainnya di luar keuntungan yang diperoleh lembaga pemasaran tersebut (Hanafiah dan Saefuddin 1983).Analisis margin pemasaran menekankan keuntungan dan biaya pada masing-masing lembaga pemasaran tiap saluran. yang ada. Margin pemasaran ikan hias air laut di pasar ikan hias Jalan Sumenep, Jakarta Pusat dapat dilihat pada Tabel 1

Margin Pemasaran Ikan Hias Air Laut di Pasar Ikan Hias Jalan Sumenep, Jakarta Pusat

\begin{tabular}{|l|l|l|l|l|}
\hline No & Grade ikan & $\begin{array}{l}\text { Harga } \\
\text { Pembudidaya } \\
(\text { Rp. })\end{array}$ & $\begin{array}{l}\text { Harga } \\
\text { Tingkat } \\
\text { Konsumen } \\
\text { (Rp.) }\end{array}$ & $\begin{array}{l}\text { Iargin } \\
\text { Pemasaran } \\
(\text { Rp. })\end{array}$ \\
\hline 1 & A & 150.000 & 300.000 & 150.000 \\
\hline 2 & B & 50.000 & 70.000 & 30.000 \\
\hline
\end{tabular}




\begin{tabular}{|l|l|l|l|l|}
\hline 3 & $\mathrm{C}$ & 25.000 & 25.000 & 0 \\
\hline
\end{tabular}

Dari Tabel dapat dilihat bahwa margin pemasaran ikan koi menguntungkan dan layak untuk dikembangkan, namun tidak komoditi bersifat menguntungkan seperti ikan koi bergrade $\mathrm{C}$ yang relatif tidak menguntungkan dan berkesan merugikan bagi pedagang karena biaya produksi lebih tinggi dari harga penjualan.

Selain dari analisis margin pemasaran yang menekankan pada keuntungan dan biaya pada masing-masing lembaga pemasaran tiap saluran dengan menggunakan perhitungan juga kita dapat mengetahui apakah suatu usaha tersebut dapat dikatakan menguntungkan atau mungkin sebaliknya. Berikut perhitungan market's share pada pemasaran ikan koi di pasar ikan hias Jalan Sumenep, Jakarta Pusat dapat dilihat pada Tabel 2.

\section{Market's Share Ikan koi di Pasar Ikan Hias Jalan Sumenep, Jakarta Pusat}

\begin{tabular}{|l|l|l|l|}
\hline Pelaku pasar & Market share & Saluran 1 & Saluran 2 \\
\hline \multirow{2}{*}{ Pembudidaya } & Harga /ekor (Rp.) & 150.000 & 150.000 \\
\cline { 2 - 4 } & MS (\%) & 21,4 & 33,3 \\
\hline \multirow{2}{*}{ Pengumpul } & Harga /ekor(Rp.) & 250.000 & \\
\cline { 2 - 3 } & MS (\%) & 35,7 & \\
\hline \multirow{2}{*}{ Pedagang } & Harga /ekor(Rp.) & 300.000 & 300.000 \\
\cline { 2 - 4 } & MS (\%) & 42,9 & 66.7 \\
\hline
\end{tabular}

Keterangan : MS = Market's Share

Berdasarkan Tabel 2 diketahui bahwa dari setiap saluran memiliki nilai market's share yang berbeda. Nilai market's share terbesar terdapat pada saluran ke-2 dengan pelaku pemasaran yaitu pembudidaya dan pedagang. Hal ini disebabkan oleh pedagang yang membeli dari pembudidaya kemudian menjualnya dengan harga yang tinggi. Nilai market's share terkecil terdapat pada saluran ke 1 dengan pelaku pemasaran yaitu pembudidaya, pengumpul, pedagang. Hal ini dikarenakan 
panjangnya saluran pemasaran dengan keterlibatan pengumpul pada proses penyalurannya sehingga keuntungan yang di dapatkan berkurang.

Untuk mengetahui besarnya bagian harga (farmer's share) yang diterima oleh pembudidaya sebagai balas jasa atas kegiatan yang dilakukan dalam produksi ikan koi, dihitung dengan cara membagi harga jual di pembudidaya dengan harga ditingkat lembaga pemasaran yang dinyatakan dalam satuan persen (\%). Farmer's share relatif sama yakni 50\% karena tidak ada selisih harga jual dari pembudidaya baik ke pengumpul ataupun pedagang.

Pengukuran efisiensi dapat juga dilakukan dengan cara mengetahui BCR para pelaku pemasaran. Bila $\mathrm{BCR} \geq 1$ maka usaha tersebut dikatakan efisien, dan bila BCR < 1 maka usaha tersebut dikatakan tidak efisien ( Mursid, 2004). Untuk mengetahui efisiensi pada pelaku pemasaran ikan koi dapat dilihat pada Tabel 3.

Tabel 3. Pengukuran Efisiensi Pada Pelaku Pemasaran

\begin{tabular}{|l|l|l|l|l|}
\hline Saluran & Pelaku & BCR & $\begin{array}{l}\text { Rata-rata } \\
\text { BCR }\end{array}$ & $\begin{array}{l}\text { Status } \\
\text { Efisiensi }\end{array}$ \\
\hline \multirow{4}{*}{ I } & Pembudidaya & 1.65 & & Efisien \\
\cline { 2 - 3 } & Pengumpul & 1.28 & \multirow{2}{*}{1.43} & Efisien \\
\cline { 2 - 3 } & Pedagang & 1.37 & & Efisien \\
\hline II & Pembudidaya & 1.65 & \multirow{2}{*}{1.51} & Efisien \\
\cline { 2 - 3 } & Pedagang & 1.37 & & Efisien \\
\hline
\end{tabular}

Berdasarkan Tabel 3 dapat disimpulkan bahwa dari ketiga pelaku pemasaran, memiliki nilai BCR di atas 1. Artinya seluruh pelaku pemasaran yaitu Pembudidaya, pengumpul dan pedagang memiliki status efisiensi pemasaran yang efisien. Tiap saluran memiliki BCR $\geq 1$. Artinya dari seluruh saluran pemasaran yang ada di pasar ikan hias Jalan Sumenep, Jakarta Pusat statusnya efisien. 


\section{KESIMPULAN}

Terdapat dua pola saluran pemasaran ikan koi (Cyprinus carpio) di Pasar Ikan Hias Jalan Sumenep, Jakarta Pusat. Saluran 1 terdiri dari pembudidaya, pengumpul, pedagang, dan konsumen yang memiliki rataan BCR: 1,43. Saluran 2 terdiri dari pembudidaya, pedagang dan konsumen yang memiliki BCR: 1,51. Melihat BCR dari tiap saluran yang $\mathrm{BCR} \geq 1$ maka status saluran pemasaran layak untuk dikembangkan.

Saluran 2 memiliki saluran pemasaran yang lebih efisien. Hal ini disebabkan pedagang langsung membeli ikan koi dari pembudidaya dan memasarkan kepada konsumen sehingga harga beli yang rendah dan harga jual yang tinggi. Semakin ringkas saluran pemasaran maka keuntungan yang diperoleh dari tiap lembaga pemasaran lebih besar.

\section{DAFTAR PUSTAKA}

Assauri, S. 2013. Pemasaran dan Pengelolaan Hasil Perikanan. Jakarta.

Hanafiah, A.M dan A.M. Saefuddin. 1986. Tataniaga Hasil Perikanan. UI Press. Jakarta. 208 Halaman.

Kotler. 2005. Management Pemasaran, Jilid I dan II. PT Indeks. Jakarta.

Mursid, M. 2004. Manajemen Pemasaran edisi pertama cetakan kedua. Jakarta: Bumi Aksara.

Nawawi, H. 2005. Metode Penelitian Bidang Sosial. Gadjah Mada University Press. Yogyakarta. 249 Halaman

Russeffendi. 2003. Dasar-dasar Penelitian Pendidikan dan Bidang Non Eksakta lainnya. Semarang. 272 Halaman.

Sudiyono, A. 2002. Pemasaran Pertanian. Universitas Muhammadiyah Malang. Malang. 214 Halaman

Sukirno, Sadono. 2008. Mikro Ekonomi Teori Pengantar. Jakarta: Raja Grafindo Persada. 